Rodzina, ekonomia i migracja. Ujęcie prawne i socjologiczno-ekonomiczne, red. Magdalena Butrymowicz, Piotr Kroczek, Kraków 2021, s. 81-121 (Biblioteczka Prawa, 4).

Elżbieta Kurzępa

https://orcid.org/oooo-0003-0032-8607

POLITECHNIKA RZESZOWSKA

\title{
Definicja mniejszości narodowych i etnicznych w polskim prawodawstwie na tle rozwiązań międzynarodowych
}

\section{Ochrona praw mniejszości narodowych i etnicznych - wprowadzenie do problematyki}

Zainteresowanie problematyką mniejszości narodowych i etnicznych na kontynencie europejskim wzrosło wraz z zakończeniem II wojny światowej, kiedy to społeczność międzynarodowa uznała, że prawne podstawy systemu bezpieczeństwa na świecie nie mogą istnieć bez odpowiednich gwarancji także dla członków zbiorowości mniejszościowych. Gwarancje w zakresie praw członków mniejszości (określanych jako mniejszości narodowe, etniczne bądź językowe) zostały włączone do międzynarodowego systemu ochrony praw człowieka, jednak, jak wskazuje większość doktryny prawa międzynarodowego, 
mają one charakter praw indywidualnych, nie zaś kolektywnych, które wskazywałyby na fakt, że grupy mniejszościowe uznane zostały za podmiot prawa międzynarodowego ${ }^{1}$.

Najbardziej znaczące rozwiązania w zakresie ochrony praw mniejszości narodowych i etnicznych opracowano w ramach Rady Europy, jednak pewne gwarancje dla społeczności mniejszościowych określono również $\mathrm{w}$ aktach prawa międzynarodowego o charakterze uniwersalnym. Było to jednak trudne zadanie, gdyż istnieją znaczące różnice pomiędzy systemami politycznymi i kulturalnymi wielu państw, w tym w zakresie postrzegania społeczności mniejszościowych, co nie sprzyja wypracowaniu jednolitych rozwiązań. Jeśli chodzi z kolei o prawodawstwo Unii Europejskiej, to kwestia ochrony mniejszości poruszana jest stosunkowo rzadko, zwykle w postaci klauzuli antydyskryminacyjnych, bez doprecyzowania charakteru społeczności mniejszościowych, do których takie ewentualne odniesienia są skierowane. $Z$ kolei w aktach prawa pierwotnego czy pochodnego dominuje raczej pojęcie "pochodzenie etniczne”, które również nie jest zdefiniowane. Należy zaznaczyć, że standardy międzynarodowe determinują zwykle określone rozwiązania także na szczeblu ustawodawstwa krajowego, choć jak dotąd wiele państw europejskich, także o charakterze multikulturowym, nie zdecydowało się na przyznanie tym szczególnym grupom obywateli żadnych uprawnień w ramach krajowego systemu prawnego. Trzeba także zauważyć, że przyznanie społecznościom mniejszościowym na gruncie prawa międzynarodowego pewnych gwarancji nie zawsze wiąże się określeniem w aktach prawa międzynarodowego ich definicji. Kwestię takiego ustalenia pozostawia się w gestii poszczególnych państw.

1 Por. R. Andrzejczuk, Prawa człowieka podstawa prawa narodów do samostanowienia, Lublin 2004, s. 94-95. 
Analizę rozwiązań normatywnych w kwestii definiowania mniejszości warto poprzedzić wyjaśnieniem rozumienia pojęcia „mniejszość” oraz pojęć „mniejszości narodowe” i „mniejszości etniczne", prezentowanych w literaturze przedmiotu. W Słowniku języka polskiego pojęcie „mniejszość” określane jest jako „mniejsza część jakiejś całości” bądź „grupa ludności danego państwa różniąca się od większości jego mieszkańców przynależnością narodową, rasową lub wyznaniową"

W nauce dominują obecnie dwa sposoby definiowania mniejszości, tj. prawnicze oraz socjologiczne. Pierwsze z nich odnosi się przede wszystkim do kryteriów liczbowych, obiektywnych, takich jak język czy religia. To właśnie $w$ definicjach prawniczych stosuje się dookreślenie, np. mniejszość narodowa, etniczna czy językowa. $Z$ kolei w definicjach o charakterze socjologicznym nacisk kładzie się w szczególności na kryteria subiektywne, takie jak poczucie tożsamości czy narodowej odrębności, wola pielęgnowania tych wartości itd. ${ }^{3}$.

Pojęcie mniejszości zostaje doprecyzowane zwykle przez określenie „narodowe" $i$ „etniczne”. To właśnie zbiorowości o takim charakterze są przede wszystkim przedmiotem zainteresowania społeczności międzynarodowej i ustawodawstw krajowych. Należy pamiętać, że wyżej określone pojęcia stosowane są często zamiennie, gdyż brak jest ich językowego dookreślenia. Powyższe terminy są także definiowane w nauce prawa, socjologii, politologii czy etnografii, jednak nie udało się opracować ich jednolitej definicji. Ich interpretacja od dawna budzi kontrowersje, co z kolei przekłada się na problemy w zakresie normatywnego wyodrębnienia mniejszości narodowych i etnicznych.

2 Słownik języka polskiego PWN, https://sjp.pwn.pl/szukaj/mniejszość.html (22.10.2018).

3 Por. G. Janusz, Ochrona praw mniejszości narodowych w Europie, Lublin 2011, s. 34 . 
W literaturze tematu „mniejszość narodowa” określana bywa jako "grupa, która znajduje się w liczebnej mniejszości wobec pozostałej ludności, posiada obywatelstwo kraju zamieszkiwania, odróżnia się od reszty obywateli cechami etnicznymi, językowymi, kulturowymi lub religijnymi oraz posiada świadomość narodową, subiektywną wolę bycia mniejszością i podkreśla swą odrębność" ${ }^{4}$. Z kolei pojęcie „mniejszość etniczna” bywa stosunkowo często używane jako synonim pojęcia „mniejszość narodowa”, choć jak wskazują definicje o charakterze socjologicznym, są to jednak określenia rodzajowo od siebie różne. W ujęciu szerszym mniejszość etniczna tym odróżnia się od mniejszości narodowej, że obejmuje również mniejszości niedające określić się jako narodowe (klanowe, plemienne, inne przednarodowe lub nienarodowe). W węższym znaczeniu jest to specyficzna grupa etniczna, nieukształtowana narodowo i niezgłaszająca postulatów typu narodowego, określana często wyłącznie w kategoriach etnograficznych5.

$\mathrm{Z}$ kolei w polskich definicjach formułowanych na gruncie piśmiennictwa „mniejszość etniczna” rozumiana bywa jako „wspólnota obejmująca obywateli danego państwa powstała w wyniku procesu historycznego, posiadająca poczucie swej odrębności, trwałe formy integracji na podstawie wspólnego pochodzenia, języka lub religii, ale niemająca aspiracji ujmowanych w kategoriach państwa”'. Prezentowane są także poglądy, iż różnica pomiędzy mniejszością narodową i etniczną jest niezwykle trudna do uchwycenia. Wydaje się jednak, że mniejszość etniczna ma szerszy zakres i zawiera w sobie

4 M. Barwiński, Pojęcie narodu oraz mniejszości narodowej i etnicznej w kontekście geograficznym, politycznym i socjologicznym, „Acta Universitatis Lodziensis. Folia Geographica Socio-Oeconomica" 2004 nr 5, s. 11.

5 M. Barwiński, Pojęcie narodu oraz mniejszości narodowej..., dz. cyt., s. 11-12.

6 H. Chałupczak, T. Browarek, Mniejszości narodowe w Polsce 1918-1995, Lublin 1998, s. 15. 
mniejszość narodową. Tę ostatnią można określić jako najdojrzalszą formę mniejszości etnicznej.

Warto zwrócić uwagę, że w piśmiennictwie podnosi się, iż podstawowym kryterium różnicującym mniejszości narodowe i etniczne jest m.in. kryterium instytucjonalne, tj. fakt, czy dana mniejszość w innym państwie stanowi większość, decyduje o jej statusie mniejszości narodowej. Przedstawiciele wspólnoty kulturowej nieposiadającej państwa są zaś mniejszością etniczną ${ }^{8}$.

\section{Uniwersalny system ochrony praw mniejszości - sposoby definiowania}

Wskazując na regulacje międzynarodowe z zakresu ochrony mniejszości narodowych i etnicznych, trzeba mieć na uwadze, że w dokumentach o charakterze uniwersalnym nie opracowano wiążącej definicji mniejszości narodowych ani mniejszości etnicznych, choć to zwykle do nich takie prawne rozwiązania są skierowane.

System ochrony mniejszości przyjęty pod auspicjami Ligi Narodów łączony jest zwykle ze zbiorem tzw. traktatów mniejszościowych (13 traktatów), które gwarantowały mniejszościom równość wobec prawa oraz prawo do posługiwania się językiem ojczystym ${ }^{9}$.

Należy zaznaczyć, że w okresie działalności Ligi Narodów określono ogólną definicję mniejszości, zgodnie z którą: „pod pojęciem

7 Por. B. Mikołajczyk, Mniejszości w prawie międzynarodowym, Katowice 1996, s. 15 .

8 Por. A. Krasnowolski, Kancelaria Senatu. Biuro Analiz i Dokumentacji, Prawa mniejszości narodowych i etnicznych w prawie międzynarodowym i polskim. Opracowania tematyczne oт-599, Warszawa 2011, s. 4.

9 Por. P. Daranowski, Prawa mniejszości w powszechnym prawie międzynarodowym, w: Sytuacja ludności polskiej na Wschodzie w świetle obowiązujacego prawa i praktyki, red. D. Górecki, Toruń 2009, s. 29-68. 
mniejszości rozumie się krąg osób innej rasy, religii lub języka niż większość ludności wchodzącego w grę państwa. Mniejszości te [ich członkowie - E. K.] są z kolei dwojakiego rodzaju: są obywatelami obcego państwa; są obywatelami wchodzącego w grę państwa" ${ }^{10}$. Zwraca uwagę duży stopień ogólnikowości niniejszej definicji, jak również możliwość zakwalifikowania do szeroko rozumianych mniejszości także grup cudzoziemców.

Jakiejkolwiek wzmianki o konieczności ochrony mniejszości narodowych i etnicznych zabrakło z kolei w Karcie Narodów Zjednoczonych powołującej w 1945 roku Organizację Narodów Zjednoczonych. Jednakże w 1947 roku Komisja Praw Człowieka funkcjonująca w ramach Organizacji Narodów Zjednoczonych powołała Podkomisję do Zapobiegania Dyskryminacji i Ochrony Mniejszości. Celem prac podkomisji było włączenie do Powszechnej deklaracji praw człowieka definicji mniejszości, jednak ostatecznie do tego nie doszło, aczkolwiek zawarto w niniejszej rezolucji klauzulę antydyskryminacyjną zabraniającą dyskryminowania m.in. ze względu na rasę, narodowość czy pochodzenie społeczne ${ }^{11}$. Dla członków społeczności mniejszościowych przewidziano zatem system ochrony indywidualnej, na równi $\mathrm{z}$ innymi ludźmi chronionymi w ramach systemu ochrony praw indywidualnych ${ }^{12}$.

Brak wzmianki w Powszechnej deklaracji praw człowieka o konieczności ochrony mniejszości był rezultatem sporu, jaki w trakcie

10 G. Janusz, Definiowanie mniejszości w dokumentach międzynarodowych i aktach prawa wewnętrznego, „Annales. Universitatis Mariae Curie-Skłodowska. Sectio K - Politologia" 15 (2008) 2, s. 96 http://dlibra.umcs.lublin.pl/dlibra/plain-content?id=6069 (22.10.2018).

11 Por. R. Bierzanek, Prawa narodów i prawa mniejszości narodowych, „Sprawy Międzynarodowe" 1990 Z. 10, s. 40.

12 Por. J. Hołda, Z. Hołda, D. Ostrowska, J. A. Rybczyńska, Prawa człowieka. Zarys wykładu, Warszawa 2008, s. 138. 
prac nad deklaracją zaistniał miedzy państwami europejskimi a państwami tzw. Nowego Świata (tj. Stanami Zjednoczonymi, Kanadą, Australią, Nową Zelandią i państwami latynoamerykańskimi), z których to druga grupa państw była przeciwna rozszerzaniu ochrony na społeczności mniejszościowe i postulowała raczej ich asymilację ${ }^{13}$. Należy jednak zwrócić uwagę na prace trzeciej sesji podkomisji, której efektem było przedłożenie 30 stycznia 1950 roku Komisji Praw Człowieka sprawozdania zawierającego podstawowe zasady ochrony mniejszości i zapobiegania dyskryminacji zatytułowanego Rezolucja w sprawie definicji mniejszości dla celów ochrony przez Podkomisje do Zapobiegania Dyskryminacji i Ochrony Mniejszości Narodów Zjednoczonych ${ }^{14}$. W dokumencie tym, który nie miał charakteru prawnie wiążącego, określono definicję mniejszości, nie precyzując jednak jej charakteru i w sposób ogólny określając, że może chodzić zarówno o odrębność etniczną, jak i religijną lub językową.

Istotny z punktu widzenia ochrony mniejszości narodowych i etnicznych w uniwersalnym systemie ochrony praw człowieka był niewątpliwie Międzynarodowy pakt praw obywatelskich i politycznych opracowany w ramach ONZ, a ściślej jego art. 27, w myśl którego: „W Państwach, w których istnieją mniejszości etniczne, religijne lub językowe, osoby należące do tych mniejszości nie mogą być pozbawione prawa do własnego życia kulturalnego, wyznawania i praktykowania własnej religii oraz posługiwania się własnym językiem wraz $\mathrm{z}$ innymi członkami danej grupy" ${ }^{15}$. O ile niniejszy przepis jest gwarancją uprawnień dla społeczności mniejszościowych, enumeratywnie

13 Por. R. Wieruszewski, Międzynarodowy pakt praw obywatelskich (osobistych) $i$ politycznych. Komentarz, Warszawa 2012, System Informacji Prawnej „LEx” (23.10.2018).

14 Por. G. Janusz, Definiowanie mniejszości..., dz. cyt., s. 97 (22.10.2018).

15 Dz. U. z 1977 r. Nr 38, poz. 167. 
w nim wyszczególnionych, o tyle nie podaje definicji tychże grup, pozostawiając kwestię ich dookreślenia prawodawstwu krajowemu. Należy także podkreślić, że podmiotami uprawnionymi na podstawie powołanego przepisu są jednostki należące do społeczności mniejszościowych, nie zaś całe grupy traktowane jako odrębne podmioty tzw. praw kolektywnych ${ }^{16}$.

Jak zauważono powyżej, pakt nie określa definicji mniejszości, podobnie jak inne akty prawa międzynarodowego o charakterze uniwersalnym. Z tego powodu opracowanie takiej definicji, choć o charakterze prawnie niewiążącym, powierzono ekspertowi onz. Działając na zlecenie Podkomisji ds. Zapobiegania Dyskryminacji i Ochrony Mniejszości Komisji Praw Człowieka onz Francesco Capotorti, na podstawie orzecznictwa międzywojennego Stałego Międzynarodowego Trybunału Sprawiedliwości, a także uwzględniając propozycje wielu państw, zaproponował następującą definicję: „mniejszość narodowa to grupa mniejsza liczebnie od reszty społeczeństwa w danym państwie, nieznajdująca się w pozycji dominującej, której członkowie, będąc obywatelami tego państwa, charakteryzują się cechami etnicznymi, wyznają religię lub posługują się językiem innym niż reszta społeczeństwa i manifestują, jeśli nawet tylko pośrednio, solidarność ukierunkowaną na zachowanie ich kultury, tradycji, religii lub języka" ${ }^{17}$. Zwraca uwagę fakt, że opracowano wyłącznie definicję mniejszości narodowej, nie odnosząc się w żaden sposób do mniejszości

16 Por. M. Jabłoński, Normatywne podstawy ochrony praw mniejszości - wybrane zagadnienia, w: J. B. Banach-Gutierrez, M. Jabłoński, Aktualne problemy ochrony wolności i praw mniejszości w Polsce i na świecie, Wrocław 2017, s. 23.

17 Z. Kedzia, W. Płowiec, Ochrona mniejszości narodowych w pracach Komitetu Praw Człowieka, w: Prawa mniejszości narodowych, red. T. Gardocka, J. Sobczak, Toruń 2010, s. 41; Minority rights: international standards and guidance for implementation, Uniated Nations Humans Rights, Office of the High Comissioner, New York-Geneva 2010, s. 2. 
etnicznych, językowych i religijnych, które z kolei uwzględniono $\mathrm{w}$ art. 27 paktu. Trzeba ponadto zauważyć, że zaproponowana definicja nawiązuje zarówno swoim charakterem do definicji historyczno-prawnych, jak i socjologicznych. Wskazano w niej bowiem nie tylko na czynniki obiektywne, tak jak m.in. liczebność, obywatelstwo, język czy religia, lecz również na czynniki subiektywne, takie jak poczucie więzi i solidarność ze wspólnotą ${ }^{18}$. Nie nawiązano natomiast w żaden sposób do ewentualnej więzi członków takiej grupy z innym narodem, który charakteryzowałby się zorganizowaną państwowością.

Innym aktem prawnym o charakterze uniwersalnym, odnoszącym się w całości do członków społeczności mniejszościowych jest Deklaracja praw osób należących do mniejszości narodowych lub etnicznych, religijnych i językowych, będąca Rezolucją Zgromadzenia Ogólnego onz nr 47/135 z dnia 10 grudnia 1992 roku. Dokument ten, choć prawnie niewiążący, posiadający jedynie charakter doradczy w stosunku do państw członkowskich, stanowi zbiór wytycznych w zakresie sposobu kształtowania sytuacji prawnej tej części społeczeństwa. W deklaracji nie zdefiniowano jednak ani mniejszości narodowych ani etnicznych. W art. 2 tego dokumentu określono natomiast, że osoby należące do mniejszości narodowych lub etnicznych, religijnych i językowych (zwane osobami należącymi do mniejszości) mają prawo do korzystania ze swej własnej kultury, do wyznawania i praktykowania swej własnej religii oraz do używania swego własnego języka, publicznie i prywatnie, swobodnie i bez ingerencji lub jakiejkolwiek formy dyskryminacji ${ }^{19}$. Dokonano zatem rozróżnienia różnych rodzajów mniejszości, pozostawiając otwartą kwestię ich doprecyzowania i zdefiniowania.

18 Por. M. Barwiński, Pojęcie narodu oraz mniejszości narodowej..., dz. cyt., s. 69.

19 https://www.spoleczenstwoobywatelskie.gov.pl/sites/default/files/deklaracja_ praw_osob_nalezacych_do_mniejszosci.pdf (23.10.2018). 


\section{Mniejszości narodowe i etniczne w regionalnych systemach ochrony praw mniejszości - sposoby definiowania}

Problematyka ochrony praw mniejszości podjęta została także w ramach regionalnych systemów ochrony praw człowieka. Trzeba wskazać przede wszystkim na Radę Europy, która posiada imponujący dorobek w zakresie ochrony społeczności mniejszościowych. Jednym z podstawowych jej dokumentów jest Konwencja o ochronie praw człowieka i podstawowych wolności ${ }^{20}$. W tym dokumencie brakuje bezpośredniego odwołania się do społeczności mniejszościowych. Zawarto natomiast na gruncie art. 14 tzw. klauzulę antydyskryminacyjną, w myśl której korzystanie z praw i wolności wymienionych w niniejszej konwencji powinno być zapewnione bez dyskryminacji wynikającej z takich powodów, jak płeć, rasa, kolor skóry, język, religia, przekonania polityczne i inne, pochodzenie narodowe lub społeczne, przynależność do mniejszości narodowej, majątek, urodzenie bądź z jakichkolwiek innych przyczyn. Zwraca uwagę fakt, że w przepisie posłużono się pojęciem „mniejszości narodowych”, w żaden sposób go jednak nie definiując.

Bardzo istotnym dokumentem $\mathrm{z}$ punktu widzenia ochrony praw mniejszości jest z kolei Karta języków regionalnych lub mniejszościowych ${ }^{21}$ przyjęta przez Komitet Ministrów jako Konwencja Rady Europy 25 czerwca 1992 roku. Z kolei 5 listopada 1992 roku tekst skierowano do podpisu przez państwa członkowskie, a karta weszła w życie 1 marca 1998 roku $^{22}$. Polska ratyfikowała ją w 2008 roku, a zaczęła

20 Dz. U. z 1993 r. Nr 61, poz. 284.

21 Dz. U. z 2009 r. Nr 137, poz. 1121.

22 E. Godlewska, M. Lesińska-Staszczuk, Ochrona praw mniejszości narodowych w Europie, w: Mniejszości narodowe w państwach Unii Europejskiej. Stan prawny i faktyczny, red. E. Godlewska, M. Lesińska-Staszczuk, Lublin 2013, s. 12. 
ona obowiązywać od 1 czerwca 2009 roku. Karta zawiera określenie szeregu celów, które w zakresie ochrony języków regionalnych lub mniejszościowych powinny osiągnąć państwa-sygnatariusze, a także środki, które umożliwią ich osiągnięcie. W jej art. 1 określono definicję języków regionalnych lub mniejszościowych stanowiąc, że „języki regionalne lub mniejszościowe oznaczają języki, które: są tradycyjnie używane na określonym terytorium państwa przez obywateli tego państwa tworzących grupę mniejszą liczebnie od pozostałej części ludności tego państwa, różnią się od oficjalnego języka (języków) tego państwa, nie obejmuje to ani dialektów oficjalnego języka (języków) tego państwa, ani języków migrantów”. Brakuje zatem jednoznacznej definicji samych mniejszości, natomiast w definicji języków objętych ochroną pojawia się jedynie kryterium liczebności, wskazujące na grupę, która takimi językami powinna się posługiwać.

Innym istotnym aktem prawnym w zakresie ochrony praw mniejszości, opracowanym w ramach Rady Europy, jest Konwencja ramowa o ochronie mniejszości narodowych $\mathrm{z}$ dnia 1 lutego $1995 \mathrm{roku}^{23}$. Weszła ona w życie 1 lutego 1998 roku. W swoim tytule zawiera odniesienie wyłącznie do mniejszości narodowych, choć w treści dokumentu brakuje definicji tych społeczności. W preambule konwencji wskazano jednak na element etniczności, jako jeden ze składających się na tożsamość osoby, choć dokument nie operuje pojęciem mniejszości etnicznej ${ }^{24}$. Wydaje się, że według postanowień konwencji etniczność,

23 Dz. U. z 2002 r. Nr 22, poz. 209.

24 Por. T. Gardocka, Mniejszości narodowe i etniczne - zagadnienie definicji, w: Prawa mniejszości narodowych, dz. cyt., s. 9o. Zgodnie z treścią preambuły do Konwencji Ramowej o Ochronie Mniejszości: „(...) zważywszy, że pluralistyczne i prawdziwie demokratyczne społeczeństwo powinno nie tylko szanować etniczną, kulturalną, językową i religijną tożsamość każdej osoby należącej do mniejszości narodowej, lecz także tworzyć odpowiednie warunki pozwalające im wyrażać, zachowywać i rozwijać tę tożsamość”. 
podobnie jak język czy religia, składa się na poczucie narodowej odrębności, która jest kluczowa w zakresie przynależności do mniejszości narodowej.

Jednocześnie należy pamiętać, że Zgromadzenie Parlamentarne Rady Europy określiło definicję „mniejszości narodowej”, która znalazła się w Rekomendacji nr 1201 z 1993 roku $^{25}$. Nie została jednak zaakceptowana przez Komitet Ministrów Rady Europy i dlatego nie włączono jej do treści konwencji ramowej. Zgodnie z jej postanowieniami mniejszość narodową należy rozumieć jako grupę osób w danym państwie, które mieszkają na terytorium tego państwa oraz są jego obywatelami, utrzymują długotrwałe, ustabilizowane i stałe związki z tym państwem, demonstrują publicznie odrębność etniczną, kulturową, religijną lub językową i są widoczne w społeczeństwie, a także są zainteresowane grupowym przetrwaniem i podtrzymywaniem wspólnej narodowej tożsamości ${ }^{26}$. Definicja ta łączy zatem elementy obiektywne i subiektywne, wskazuje na warunek obywatelstwa państwa, w którym dana społeczność zamieszkuje, jednak nie określa wymogu utożsamiania się z narodem, który byłby zorganizowany we własnym państwie. Etniczność została natomiast uznana za jeden z elementów narodowej tożsamości. Można zatem postawić tezę, że według postanowień rekomendacji nie istnieje mniejszość narodowa bez odrębności etnicznej, a w takim razie ta ostatnia jest określeniem szerszym.

Dla omawianego zagadnienia istotne są również rozwiązania dotyczące społeczności mniejszościowych opracowanych w ramach

25 Recommendation 1201 (1993) on Additional protocol on the rights of minorities to the European Convention on Human Rights, Doc. CoE/Pa/Rec 2101 (1993), Strasbourg 01.02.1993, s. 2-5.

26 Por. S. Łodziński, Równość i różnica. Mniejszości narodowe w porzadku demokratycznym w Polsce po 1989 roku, Warszawa 2005, s. 49. 
Konferencji Bezpieczeństwa i Współpracy w Europie (od 1 stycznia 1995 roku Organizacji Bezpieczeństwa i Współpracy w Europie). W początkowym okresie współpracy państw w ramach tej organizacji o charakterze regionalnym w sposób bardzo ogólny odniesiono się do kwestii mniejszości. W Akcie końcowym квWE, przyjętym 1 sierpnia 1975 roku określono jedynie, że „państwa uczestniczące, na których terytorium znajdują się mniejszości narodowe, będą szanować prawo osób należących do mniejszości do równości wobec prawa, dadzą im pełną możliwość rzeczywistego korzystania z praw człowieka i podstawowych wolności i w ten sposób będą chronić uzasadnione interesy w tej dziedzinie" ${ }^{27}$. Dokument ten, w którym posłużono się określeniem „mniejszości narodowej”, w żaden sposób jej nie definiuje. Wypada dodać, że jakkolwiek na przestrzeni lat system ochrony mniejszości ulegał sukcesywnemu udoskonalaniu w ramach квWE, a następnie od 1 stycznia 1995 roku w ramach OBWE (Organizacji Bezpieczeństwa i Współpracy w Europie), to jednak nie zdecydowano się na opracowanie wspólnej definicji mniejszości narodowych. W dokumentach opracowanych w ramach tej współpracy pojawia się wyłącznie odniesienie do mniejszości narodowych, nie zaś etnicznych. Z kolei na podstawie Dokumentu helsińskiego Wyzwania czasu przemian z 10 lipca 1992 roku zapadły ustalenia, które doprowadziły do powołania instytucji Wysokiego Komisarza квше/овWE ds. Mniejszości Narodowych ${ }^{28}$. W dokumencie zaniechano określenia definicji mniejszości narodowych, a Wysokiemu Komisarzowi przyznano status instrumentu głównie o charakterze politycznym;

27 E. Godlewska, M. Lesińska-Staszczuk, Ochrona praw mniejszości narodowych $w$ Europie, dz. cyt., s. 15.

28 Por. M. Jeziorski, Wysoki Komisarz KвWE do spraw Mniejszości Narodowych, „Sprawy Międzynarodowe” 1994 nr 2 (47), s. 135-139; K. Pękalska, Charakter prawny i funkcje Wysokiego Komisarza овWE ds. Mniejszości Narodowych, „Humanities and Social Sciences” XxII, 24 (2/2017), s. 217. 
jest bowiem uprawniony do zapobiegania konfliktom i monitorowania sytuacji mniejszości narodowych, nie zaś do rozstrzygania indywidualnych skarg członków takich społeczności ${ }^{29}$.

Odnosząc się z kolei do rozwiązań Unii Europejskiej w zakresie ochrony i definiowania mniejszości narodowych i etnicznych, trzeba zaznaczyć, że o ile zauważalny jest w ostatnich latach wzrost zainteresowania problematyką ochrony mniejszości, o tyle w unijnym systemie prawa brakuje legalnej definicji mniejszości, choć rzecz jasna w dokumentach unijnych pojawiają się określenia odnoszące się do mniejszości. Można tu wspomnieć chociażby o tzw. kryteriach kopenhaskich, które opracowane zostały w 1993 roku w ramach szczytu Rady Europejskiej w Kopenhadze. Określono w nich kryteria, których spełnienie miało umożliwić państwom europejskim ubieganie się o członkostwo. W pierwszej grupie kryteriów wskazano na: stabilność instytucji gwarantujących demokrację, rządy prawa, przestrzeganie praw człowieka i ochronę mniejszości. Mimo że kryteria mówiły ogólnie o mniejszościach, to w składanych raportach przedakcesyjnych wyraźnie odnoszono zobowiązania w tym zakresie do mniejszości narodowych ${ }^{30}$.

Zwraca uwagę Traktat z Lizbony zmieniający Traktat o Unii Europejskiej i Traktat ustanawiający Wspólnotę Europejską z dnia 13 grudnia $2007 \mathrm{roku}^{31}$. W jego artykule 1a określono, że „Unia opiera się na wartościach poszanowania godności osoby ludzkiej, wolności, demokracji, równości, państwa prawnego, jak również poszanowania praw człowieka, w tym praw osób należących do mniejszości. Wartości te są wspólne Państwom Członkowskim w społeczeństwie opartym

29 Por. K. Pękalska, Charakter prawny i funkcje..., dz. cyt., s. 218.

30 Por. G. Pawlikowski, System ochrony praw osób należacych do mniejszości narodowych i etnicznych w Europie, „Polityka i Społeczeństwo” $2011 \mathrm{nr}$ 8, s. 285.

31 Dz. U. z 2009 r. Nr 203, poz. 1569. 
na pluralizmie, niedyskryminacji, tolerancji, sprawiedliwości, solidarności oraz na równości kobiet i mężczyzn". Zatem poszanowanie praw mniejszości uzyskało rangę wartości Unii Europejskiej. W traktacie nie doprecyzowano jednak charakteru tych mniejszości.

Kolejnym dokumentem jest Karta praw podstawowych Unii Europejskiej. W jej artykule 21, stanowiącym swego rodzaju klauzulę antydyskryminacyjną, postanowiono, że zakazana jest wszelka dyskryminacja w szczególności ze względu na płeć, rasę, kolor skóry, pochodzenie etniczne lub społeczne, cechy genetyczne, język, religię lub przekonania, poglądy polityczne lub wszelkie inne poglądy, przynależność do mniejszości narodowej, majątek, urodzenie, niepełnosprawność, wiek lub orientację seksualną ${ }^{32}$. W niniejszym przepisie posłużono się zatem pojęciem mniejszości narodowych oraz pochodzenia etnicznego, co wskazuje na przyjęcie odmiennego znaczenia tych określeń. Nie dokonano jednak legalnego rozróżnienia wskazanych pojęć.

Warto podkreślić, że pojęcie pochodzenia etnicznego pojawiło się już na gruncie Traktatu z Amsterdamu zmieniającego Traktat o Unii Europejskiej, traktaty ustanawiające Wspólnoty Europejskie i niektóre związane $\mathrm{z}$ nim akty ${ }^{33}$. Na jego podstawie do Traktatu ustanawiającego Wspólnotę Europejską dodano art. 6a, w myśl którego, „bez uszczerbku dla innych postanowień niniejszego Traktatu i w granicach kompetencji, które Traktat powierza Wspólnocie, Rada, stanowiąc jednomyślnie na wniosek Komisji i po konsultacji z Parlamentem Europejskim, może podjąć środki niezbędne w celu zwalczania wszelkiej dyskryminacji ze względu na płeć, rasę lub pochodzenie

32 Tekst Karty Praw Podstawowych uE ze strony https://bip.ms.gov.pl/Data/Files/_public/bip/prawa_czlowieka/onz/karta.pdf (29.10.2018). 
etniczne, religię lub światopogląd, niepełnosprawność, wiek lub orientację seksualną".

Podobne postanowienia posiadające charakter klauzuli antydyskryminacyjnych znalazły się $\mathrm{w}$ traktacie o funkcjonowaniu Unii Europejskiej, a także w aktach prawnych o charakterze wtórnym, tj. w dyrektywach, rezolucjach czy zaleceniach, jednak w żadnym nie określono definicji mniejszości. Należy jednak zauważyć, że wszystkie postanowienia unijne dotyczące ochrony mniejszości mają postać walki z dyskryminacją m.in. związaną z pochodzeniem etnicznym ${ }^{34}$.

Ciekawy wydaje się fakt, że w zasadzie jedyne definicje społeczności mniejszościowych określone w regionalnym systemie praw człowieka zostały zawarte $\mathrm{w}$ dokumentach opracowanych $\mathrm{w}$ ramach Inicjatywy Środkowoeuropejskiej oraz w ramach Wspólnoty Niepodległych Państw. W dokumentach tych posłużono się wyłącznie pojęciem „mniejszość narodowa”, nie używając natomiast pojęcia etniczności. Chodzi m.in. o Instrument Inicjatywy Środkowoeuropejskiej ochrony praw mniejszości przedstawiony do podpisu w Turynie $\mathrm{w}$ dniu 19 listopada 1994 roku. Zgodnie z jego postanowieniami mniejszość narodową określa się jako grupę mniejszą liczebnie od pozostałej części ludności w danym państwie, której członkowie, będący obywatelami danego państwa, mają etniczne, religijne lub językowe cechy odróżniające je od pozostałej części ludności i kierują się wolą zachowania własnej kultury, tradycji, religii lub języka ${ }^{35}$. Należy zauważyć, że w definicji tej występują zarówno elementy obiektywne (obywatelstwo, odmienność etniczna, religijna lub językowa), jak i subiektywne (wola zachowania własnej kultury, tradycji, religii lub języka). Brak natomiast wymogu identyfikowania się z narodem zorganizowanym

34 Por. E. Godlewska, M. Lesińska-Staszczuk, Ochrona praw mniejszości narodowych $w$ Europie, dz. cyt., s. 23.

35 Por. G. Janusz, Definiowanie mniejszości..., dz. cyt., s. 101 (29.10.2018). 
we własnym państwie. Dokument ten nie ma jednak rangi umowy międzynarodowej i nie jest prawnie obowiązujący ${ }^{36}$.

Drugim z dokumentów jest Konwencja Wspólnoty Niepodległych Państw o ochronie praw osób należących do mniejszości narodowych, którą przyjęto w Moskwie 21 października 1994 roku. W jej art. 1 określono, że „dla celów niniejszej Konwencji pod pojęciem osób należących do mniejszości narodowych rozumie się osoby stale zamieszkałe na terytorium jednej z Umawiających się Stron i mające jej obywatelstwo, które swoim etnicznym pochodzeniem, językiem, kulturą religią lub tradycją odróżniają się od pozostałej ludności danej Umawiającej się Strony" ${ }^{37}$. Zwraca zatem uwagę fakt, że definicja mniejszości narodowych przyjęta na gruncie Konwencji Wspólnoty Niepodległych Państw jest zbliżona w swoim brzmieniu do tej określonej w Instrumencie Inicjatywy Środkowoeuropejskiej (m.in. odwołuje się do obywatelstwa członków społeczności mniejszości), choć brakuje w niej tzw. przesłanek subiektywnych, a etniczność jest jednym z elementów odróżniających mniejszość narodową od reszty społeczeństwa.

Reasumując, opracowanie jednolitej definicji mniejszości narodowych i etnicznych, czy to w międzynarodowych aktach prawnych o charakterze uniwersalnym, czy też regionalnym jest bez wątpienia zadaniem trudnym i w obecnej chwili - jak się wydaje - nie stanowi priorytetu dla społeczności międzynarodowej. Osiągnięcie konsensusu w tej dziedzinie, zwłaszcza w sferze uniwersalnej, jest ograniczone przeciwstawnymi interesami wielu państw i ich różnym

36 Por. L. M. Nijakowski, S. Łodziński, Mniejszości narodowe i etniczne w Polsce. Informator 2003, Warszawa 2003, s. 77.

37 G. Janusz, Prawa mniejszości w systemie ochrony praw człowieka Wspólnoty Niepodległych Państw (analiza dokumentów), w: Kultura pogranicza-pogranicze kultur, red. A. Bobryk, Siedlce-Pułtusk 2005, s. 157n. 
postrzeganiem problemu mniejszości narodowych i etnicznych, uzależnionym od aktualnej wewnątrzpaństwowej sytuacji w tym zakresie i społecznych nastrojów. Brak definicji mniejszości, czy to narodowych, czy etnicznych na gruncie aktów prawa międzynarodowego i pozostawienie tej kwestii w gestii regulacji krajowych przyznaje państwom-stronom uczestniczącym w międzynarodowym systemie ochrony praw człowieka pewien margines swobody i możliwość dostosowania zakresu ochrony mniejszości do realnych możliwości państw w tym zakresie oraz aktualnych potrzeb. Wiąże się zarazem z obawą, że jednak mimo formalnego przystąpienia do międzynarodowego systemu ochrony praw człowieka, w tym ochrony mniejszości, brak ten pozwoli państwom na bierność w zakresie wdrożenia określonych prawem gwarancji.

\section{Polskie rozwiązania w zakresie definiowania mniejszości narodowych i etnicznych}

Odnosząc się z kolei do polskich rozwiązań w zakresie definiowania mniejszości, trzeba zauważyć, że legalna definicja mniejszości narodowych i etnicznych pojawiła się w ustawodawstwie polskim dopiero na gruncie ustawy z dnia 6 stycznia 2005 roku o mniejszościach narodowych i etnicznych oraz o języku regionalnym [dalej: u.m.n.e.] ${ }^{38}$, choć problem mniejszości obecny był w polskim dyskursie publicznym znacznie wcześniej. Szacuje się, że w okresie II RP mniejszości narodowe stanowiły około 30\% ludności kraju (przede wszystkim Ukraińcy, Żydzi, Białorusini i Niemcy) ${ }^{39}$. Ten wielonarodowościowy charakter Polska utraciła po II wojnie światowej na skutek okupacyjnej

38 Dz. U. z 2017 r., poz. 823.

39 Por. C. Brzoza, Polska w czasach niepodległości i drugiej wojny światowej 1918-1945, Kraków 2001, s. 51. 
polityki III Rzeszy, która doprowadziła do zagłady znacznej części mniejszości żydowskiej oraz romskiej. W okresie PRL kwestię ochrony mniejszości odsunięto na dalszy plan, natomiast wzrost zainteresowania tą problematyką nastąpił po transformacji ustrojowej w 1989 roku, kiedy to Polska stała się m.in. stroną międzynarodowych umów, które taką ochronę mniejszości gwarantowały ${ }^{40}$.

Według narodowego spisu powszechnego z 2011 roku ludność o wyłącznie polskich identyfikacjach narodowościowych obejmowała blisko 37394 tys. osób, co stanowi 97,1\% mieszkańców Polski. Ponad 871 tys. osób zadeklarowało zarówno polską, jak i inną niż polska tożsamość narodowo-etniczną. Deklarujący wyłącznie niepolską przynależność narodową lub etniczną stanowią grupę przeszło 596 tys. osób (więcej niż podczas narodowego spisu powszechnego w 2002 roku wówczas narodowość wyłącznie niepolską zadeklarowało 445 tys. obywateli polskich $\left.{ }^{41}\right)^{42}$. Najwięcej osób wskazało podczas spisu w 2011 roku, jako inną narodowość niż polska, narodowość śląską - 846,7 tys. mieszkańców Polski, kolejno: kaszubską - 232,5 tys., niemiecką 147,8 tys., ukraińską - 51 tys., białoruską $-46,8$ tys., romską - 17 tys., rosyjską - 13 tys., amerykańską - 11,8 tys., angielską - 10,5 tys.,

40 Por. E. Kurzępa, Sytuacja administracyjnoprawna mniejszości narodowych i etnicznych w Polsce, Toruń 2009, s. 11-12.

41 GUS, Wyniki Narodowego Spisu Powszechnego Ludności i Mieszkań w 2002 roku w zakresie deklarowanej narodowości oraz języka używanego w domu, https:// stat.gov.pl/spisy-powszechne/narodowe-spisy-powszechne/narodowy-spis-powszechny-2002/wyniki-narodowego-spisu-powszechnego-2002-narodowoscioraz-jezyka/ (10.11.2018).

42 W spisie ludności z 2011 roku po raz pierwszy w historii polskich spisów powszechnych umożliwiono mieszkańcom Polski wyrażanie złożonych tożsamości narodowo-etnicznych poprzez zadawanie osobom spisywanym dwóch pytań o przynależność narodowo-etniczną (GUs, Struktura narodowo-etniczna, językowa i wyznaniowa ludności Polski. Narodowy Spis Powszechny Ludności i Mieszkań 2011, Warszawa 2015, s. 19). 
łemkowską - 10,5 tys., włoską - 8,6 tys., francuską - 8 tys., litewską 7,9 tys., żydowską - 7,5 tys., hiszpańską - 4 tys., wietnamską - 4 tys., holenderską - 3,9 tys., grecką - 3,6 tys., ormiańską - 3,6 tys., czeską 3,4 tys., słowacką - 3,2 tys., kociewską - 3,1 tys. ${ }^{43}$ Co istotne - nie wszystkie spośród tych grup społecznych objęte zostały definicją mniejszości narodowych bądź etnicznych na gruncie u.m.n.e.

Niektóre z wyżej wymienionych grup to grupy imigrantów przybyłych na terytorium Polski stosunkowo niedawno, wobec czego nie spełniają warunku tradycyjnego zamieszkiwania na terytorium RP, niezbędnego do uzyskania statusu mniejszości w świetle aktualnych rozwiązań prawnych.

Warto zauważyć, że mimo iż legalną definicję mniejszości ustalono dopiero w 2005 roku, to jednak w deklaracji interpretacyjnej do Konwencji ramowej o ochronie mniejszości narodowych, przyjętej przez Radę Ministrów w 2000 roku, określono, co będzie rozumiane przez pojęcie mniejszości narodowej. W deklaracji stwierdzono, że pod pojęciem mniejszości rozumie się mniejszości narodowe zamieszkałe na terytorium Rzeczypospolitej Polskiej, których członkowie są obywatelami polskimi. Niniejsza definicja w zasadzie nie precyzuje, jakie cechy danej społeczności, poza obywatelstwem, decydują o przynależności do mniejszości narodowej, co zresztą wpisuje się $\mathrm{w}$ tendencje międzynarodowe w tym zakresie.

Ponadto należy wspomnieć o Traktacie między Rzeczpospolitą Polską a Republiką Federalną Niemiec o dobrym sąsiedztwie i przyjaznej współpracy z dnia 17 czerwca 1991 roku $^{44}$. W tej umowie określono jedynie definicję mniejszości niemieckiej i uznano, że należą do niej

43 Por. S. Łodziński, K. Warmińska, G. Gudaszewski, Mniejszości narodowe $i$ etniczne w Polsce $w$ świetle Narodowego Spisu Powszechnego Ludności z 2011 roku, Warszawa 2015, s. 65-66. 
osoby posiadające polskie obywatelstwo, posiadające niemieckie pochodzenie albo przyznające się do języka, kultury lub tradycji niemieckiej. Definicja ta zawiera zarówno elementy obiektywne (obywatelstwo, pochodzenia), jak i subiektywne (utożsamianie się $\mathrm{z}$ wartościami narodu niemieckiego).

W tym kontekście watro przywołać również Traktat między Rzeczpospolitą Polską a Republiką Litewską o przyjaznych stosunkach i dobrosąsiedzkiej współpracy zawarty w dniu 26 kwietnia 1994 roku $^{45}$. W art. 13 stanowi on, że osoby należące do mniejszości polskiej w Republice Litewskiej, czyli osoby posiadające obywatelstwo litewskie, które są polskiego pochodzenia albo przyznają się do narodowości, kultury lub tradycji polskiej oraz uznają język polski za swój język ojczysty, a także osoby należące do mniejszości litewskiej w Rzeczypospolitej Polskiej, czyli osoby posiadające obywatelstwo polskie, które są litewskiego pochodzenia albo przyznają się do narodowości, kultury lub tradycji litewskiej oraz uznają język litewski za swój język ojczysty, mają prawo indywidualnie lub wespół z innymi członkami swej grupy do swobodnego wyrażania, zachowania i rozwijania swej tożsamości narodowej, kulturowej, językowej i religijnej, bez jakiejkolwiek dyskryminacji i przy zachowaniu pełnej równości wobec prawa. Definicja mniejszości litewskiej w Polsce, jak i mniejszości polskiej na Litwie, jest w swojej konstrukcji zbliżona do definicji mniejszości niemieckiej zawartej w umowie bilateralnej zawartej z Niemcami i łączy zarówno elementy subiektywne, jak i obiektywne. W niniejszym traktacie brakuje natomiast odniesienia do mniejszości etnicznych, a etniczność nie jest określona jako element tożsamości narodowej.

Mimo iż normatywna definicja mniejszości narodowych i etnicznych weszła do polskiego porządku prawnego w 2005 roku, to jednak 
na gruncie innych aktów prawnych już wcześniej pojawiały się określenia wskazujące na te grupy społeczne. Należy chociażby zwrócić uwagę na ustawę z dnia 7 października 1999 roku o języku polskim, w której posłużono się pojęciem „mniejszości narodowych i etnicznych” ${ }^{46}$, czy na ustawę z dnia 7 września 1991 roku o systemie oświaty, w której także przyznano gwarancje w zakresie edukacji dla mniejszości narodowych i mniejszości etnicznych (art. 13) ${ }^{47}$. Z kolei w ustawie z dnia 6 czerwca 1997 roku Kodeks karny ustawodawca posługuje się pojęciami "grupa narodowa”, „grupa etniczna” (art. 118), „przynależność narodowa”, „przynależność etniczna” (art. 119), wyraźnie rozróżniając te dwie społeczności ${ }^{48}$.

Nie można rzecz jasna pominąć Konstytucji RP Z 1997 roku9, która w art. 27 i 35 odwołuje do społeczności mniejszościowych, gwarantując im ochronę tożsamości, w tym językowej, w żaden sposób nie definiując jednak tych zbiorowości. W art. 27 ustawy zasadniczej następuje odwołanie wyłącznie do mniejszości narodowych, zaś w art. 35 zarówno do mniejszości narodowych, jak i etnicznych, co być może stało się powodem późniejszego wyraźnego rozróżnienia na gruncie ustawowym tych dwóch grup odniesienia.

Jedyna legalna definicja mniejszości narodowych i etnicznych została określona na gruncie wspomnianej wcześniej ustawy z dnia 6 stycznia 2006 roku o mniejszościach narodowych i etnicznych oraz o języku regionalnym. Kwestia ustalenia takiej definicji była przedmiotem wielu kontrowersji w trakcie prac nad ustawą, a w projektach tejże ustawy opracowanych w ramach sejmowej Komisji Mniejszości Narodowych i Etnicznych pomijano początkowo kwestię rozróżnienia tych

46 Dz. U. z 2018 r., poz. 931.

47 Dz. U. z 2018 r., poz. 1457 z późn. zm.

48 Dz. U. z 2018 r., poz. 1600.

Dz. U. z 1997 r. Nr 78, poz. 483 z późn. zm. 
dwóch mniejszości, posługując się jednym określeniem „mniejszości narodowej lub etnicznej", do którego opracowano jedną definicję ${ }^{50}$. Zgodnie z definicją zawartą w projekcie ustawy o mniejszościach narodowych i etnicznych w Rzeczypospolitej Polskiej przez mniejszość narodową lub etniczną rozumie się grupę obywateli Rzeczypospolitej Polskiej o odrębnym pochodzeniu, tradycyjnie zamieszkałą na terytorium Rzeczypospolitej Polskiej, pozostającą w mniejszości w stosunku do reszty obywateli, charakteryzującą się dążeniem do zachowania swojego języka, obyczajów, tradycji, kultury, religii lub świadomości narodowej lub etnicznej. Pierwotna definicja mniejszości stanowiła zatem połączenie elementów obiektywnych i subiektywnych, wpisując się zarówno w ujęcie prawne, jak i socjologiczne. Przewidywała możliwość uznania za mniejszość wyłącznie tych społeczności, których członkowie są obywatelami polskimi i tradycyjnie zamieszkują na terytorium Polski, choć nie sprecyzowano co pod tym określeniem należy rozumieć. W pierwotnej wersji definicji zabrakło także enumeratywnego wyliczenia społeczności uznanych za mniejszości narodowe i etniczne, co z kolei zostało uwzględnione w aktualnej definicji tych społeczności. Ponadto nie wyjaśniono w żaden sposób pojęcia narodowości i etniczności, określając jedynie, że dążenie do zachowania świadomości narodowej bądź etnicznej jest elementem koniecznym do uznania danej osoby jako członka mniejszości.

Definicję mniejszości narodowych i etnicznych zawarto na gruncie art. 2 u.m.n.e., wyraźnie rozróżniając te dwa pojęcia, co w zasadzie nie zdarza się na gruncie aktów prawa międzynarodowego. Definicja ma charakter rozbudowany i w odróżnieniu od jej pierwotnego brzmienia, zaprezentowanego powyżej, oprócz określenia przesłanek, które

50 Zob. Druk sejmowy nr 223, Sejm Iv kadencji, http://orka.sejm.gov.pl/Druki4ka. nsf/wgdruku/223 (3.11.2018). 
warunkują przyznanie statusu mniejszości, zawiera także zamknięty katalog mniejszości narodowych i etnicznych. Katalog ten wzbudził duże kontrowersje, zwłaszcza w tych środowiskach, które mimo pretendowania do statusu mniejszości, nie zostały objęte ustawową definicją. Chodzi przede wszystkim o społeczność śląską oraz kaszubską, choć ta ostatnio uzyskała na gruncie normatywnym gwarancję ochrony języka, gdyż język kaszubski uzyskał status języka regionalnego.

W myśl art. 2 ust. 1 u.m.n.e. mniejszością narodową, w rozumieniu ustawy, jest grupa obywateli polskich, która spełnia łącznie następujące warunki:

1) jest mniej liczebna od pozostałej części ludności Rzeczypospolitej Polskiej;

2) w sposób istotny odróżnia się od pozostałych obywateli językiem, kulturą lub tradycją;

3) dąży do zachowania swojego języka, kultury lub tradycji;

4) ma świadomość własnej historycznej wspólnoty narodowej i jest ukierunkowana na jej wyrażanie i ochronę;

5) jej przodkowie zamieszkiwali obecne terytorium Rzeczypospolitej Polskiej od co najmniej 100 lat;

6) utożsamia się z narodem zorganizowanym we własnym państwie.

Ponadto za mniejszość narodową uznano następujące mniejszości: białoruską, czeską, litewską, niemiecką, ormiańską, rosyjską, słowacką, ukraińską, żydowską.

Z kolei zgodnie $z$ art. 2 ust. 3 u.m.n.e. mniejszością etniczną, w rozumieniu ustawy, jest grupa obywateli polskich, która spełnia łącznie następujące warunki:

1) jest mniej liczebna od pozostałej części ludności Rzeczypospolitej Polskiej;

2) w sposób istotny odróżnia się od pozostałych obywateli językiem, kulturą lub tradycją;

3) dąży do zachowania swojego języka, kultury lub tradycji; 
4) ma świadomość własnej historycznej wspólnoty etnicznej i jest ukierunkowana na jej wyrażanie i ochronę;

5) jej przodkowie zamieszkiwali obecne terytorium Rzeczypospolitej Polskiej od co najmniej 100 lat;

6) nie utożsamia się $\mathrm{z}$ narodem zorganizowanym we własnym państwie.

Za mniejszości etniczne uznaje się następujące mniejszości: karaimską, lemkowską, romską, tatarską.

Mając na uwadze powyższe przepisy, można stwierdzić, że definicje mniejszości narodowych i mniejszości etnicznych stanowią kombinację elementów subiektywnych i obiektywnych, a zatem wpisują się zarówno w ujęcie prawne, jak i socjologiczne mniejszości. Do elementów obiektywnych zaliczyć można: mniejszą liczebność od pozostałej części ludności Polski, odróżnianie się od reszty obywateli językiem, kulturą lub tradycją, tradycyjne (co najmniej 10o-letnie) zamieszkiwanie na terytorium Polski. Z kolei do elementów subiektywnych zaliczyć należy z kolei: dążenie do zachowania swojego języka, kultury lub tradycji, ukierunkowanie na wyrażanie i ochronę własnej historycznej wspólnoty narodowej lub etnicznej, a także utożsamianie bądź też nie z narodem zorganizowanym we własnym państwie.

Czynnikiem odróżniającym mniejszość narodową od mniejszości etnicznej jest w zasadzie kwestia utożsamiania się z narodem zorganizowanym we własnym państwie (mniejszość narodowej) oraz brak utożsamiania się z narodem zorganizowanym we własnym państwie (mniejszość etniczna), a także świadomość własnej historycznej wspólnoty narodowej (mniejszości narodowe) bądź etnicznej (mniejszości etniczne). Elementy obiektywne obu definicji w zasadzie nie budzą wątpliwości i pozostają tożsame z tendencjami międzynarodowym, w tym także z definicją mniejszości narodowej określoną w Rekomendacji nr 1201 opracowanej w ramach Rady Europy, która jak już podkreślano nie ma mocy wiążącej. 
Polski ustawodawca przewidział, że status mniejszości narodowych i etnicznych mogą uzyskać wyłącznie grupy obywateli polskich. Wymóg obywatelstwa państwa, które zapewnia ochronę mniejszości, pojawia się w rozwiązaniach międzynarodowych zarówno o charakterze bilateralnym, jak i multilateralnym (m.in. Instrument Inicjatywy Środkowoeuropejskiej ochrony praw mniejszości), choć w literaturze przedmiotu podnosi się, że gremia międzynarodowe postulują odejście od tego $\mathrm{wymogu}^{51}$. Na razie jednak brak politycznego klimatu ku temu, by z takiej przesłanki ochrony mniejszości zrezygnować. Wymóg obywatelstwa wiąże się z funkcjonowaniem tzw. klauzuli bezpieczeństwa, obejmujących dwie kwestie: zagwarantowanie, aby korzystanie przez osoby należące do mniejszości narodowych z przyznanych im praw odbywało się zgodnie z prawem międzynarodowym (co wyraźnie przewidziano m.in. w umowach dwustronnych zawartych przez Polskę), a po drugie zagwarantowanie lojalności obywatelskiej osób należących do mniejszości narodowych w stosunku do państwa, w którym zamieszkująa ${ }^{52}$. Odwoływanie się zatem do kryterium obywatelstwa stanowi swego rodzaju zabezpieczenie dla państwa, że zagwarantowanie społecznościom mniejszościowych pewnych praw nie będzie skutkowało w przyszłości zagrożeniem dla jego niepodległości czy terytorialnej integralności. Polski ustawodawca zadecydował, że prawa osób, które nie posiadają polskiego obywatelstwa, a chcą pielęgnować swoją narodową bądź etniczną odrębność, będą chronione na gruncie innych aktów prawnych (np. ustawy o cudzoziemcach), czy też klauzul antydyskryminacyjnych o ogólnym charakterze. Warunek obywatelstwa wyklucza także uznanie za mniejszości

51 Por. J. Barcz, Rola standardów квWE w ustalaniu treści klauzul dotyczących ochrony mniejszości narodowych w traktatach bilateralnych Polski z pierwszej połowy lat dziewięćdziesiątych Xx wieku, w: Prawa mniejszości narodowych, dz. cyt., s. 21.

52 Por. J. Barcz, Rola standardów кBWE w ustalaniu treści klauzul..., dz. cyt., s. 34. 
narodowe lub etniczne grup osób posiadających obywatelstwo kraju członkowskiego Unii Europejskiej i tworzących tzw. społeczności pracowników imigrantów, czy też grupy imigrantów spoza państw Unii Europejskiej, choć rzecz jasna możliwość wyrażania ich odrębności narodowej lub etnicznej powinna wynikać z ogólnych standardów ochrony praw człowieka ${ }^{53}$.

W zasadzie nie budzą wątpliwości wspólne dla dwóch typów mniejszości elementy definicji, tj.: mniejsza liczebność od pozostałej - dominującej części ludności Rzeczypospolitej Polskiej, odróżnianie się w sposób istotny od pozostałych obywateli językiem, kulturą lub tradycją oraz dążenie do zachowania swojego języka, kultury lub tradycji. Warunków takich nie spełnią zatem te zbiorowości, które uległy silnej asymilacji kulturowej z dominującą w państwie pod względem narodowościowym grupą i nie wykazują potrzeby wyrażania i zachowania swojej narodowej bądź etnicznej odrębności.

Pewnym zaskoczeniem okazało się włączenie do definicji mniejszości narodowych i etnicznych wymogu zamieszkiwania przez przodków społeczności mniejszościowych obecnego terytorium Rzeczypospolitej Polskiej od co najmniej 100 lat. Takie doprecyzowanie kryterium tradycyjnego zamieszkiwania jest raczej niespotykane na gruncie rozwiązań międzynarodowych. Należy zaznaczyć, że w projektach u.m.n.e. znalazły się początkowo przepisy, w których zastosowano nieostre określenie „tradycyjnych mniejszości”" ${ }^{4}$. Bez wątpienia pozostawienie tak niedookreślonego kryterium spowodowałoby chaos interpretacyjny oraz otwartą drogę do zgłaszania przez inne

53 Por. E. Michalik, H. Chałupczak, Mniejszości narodowe i etniczne w okresie transformacji i integracji, Lublin 2006, s. 304-307.

54 Por. S. Łodziński, Kancelaria Sejmu. Biuro Studiów i Ekspertyz, Wyrównanie czy uprzywilejowanie? Spory dotyczące projektu ustawy o ochronie mniejszości narodowych (1989-2005). Raport nr 232, Warszawa 2005, s. 3. 
społeczności roszczeń w zakresie przyznania statusu mniejszości. Trzeba zwrócić uwagę, że doprecyzowanie tego wymogu przez ustawodawcę pozbawia możliwości uzyskania statusu mniejszości przez grupy ludności wietnamskiej, greckiej czy chińskiej z tego względu, że społeczności te przybyły na terytorium Polski w drugiej połowie $\mathrm{xx}$ wieku ${ }^{55}$.

Najistotniejsze z punktu widzenia rozróżnienia mniejszości narodowych i etnicznych na gruncie u.m.n.e., a jednocześnie budzące największe kontrowersje jest kryterium świadomość własnej historycznej wspólnoty narodowej i etnicznej oraz utożsamianie się z narodem zorganizowanym we własnym państwie lub też jego brak. Kluczowe wydaje się wobec tego rozróżnienie pojęcia narodu oraz grupy etnicznej, choć należy pamiętać, że ani na gruncie normatywnym, ani na gruncie naukowym nie istnieje jednolita definicja tych pojęć; stanowią one przedmiot rozważań socjologii, historii, psychologii, politologii czy prawa międzynarodowego. Definicje narodu można podzielić na dwa rodzaje. Genetyczne, kładące nacisk na czynniki, które złożyły się na jego powstanie (traktują one naród jako produkt rozwoju historycznego) oraz strukturalne, określające naród poprzez wskazanie cech charakteryzujących daną grupę społeczną właśnie jako naród ${ }^{56}$. Definicje genetyczne stanowią, że naród jest wynikiem wspólnych losów historycznych, wręcz wytworem rozwoju historycznego, wspólnotą ukształtowaną na gruncie pewnych cech wspólnych dla grupy narodowej. Częściej pojawiają się z literaturze tematu definicje strukturalne, które określają naród poprzez wskazywanie cech charakteryzujących daną grupę społeczną właśnie jako naród ${ }^{57}$. Naród definiowany jest w ujęciu strukturalnym zwykle jako wspólnota

55 Por. E. Kurzępa, Sytuacja administracyjnoprawna..., dz. cyt., s. 21.

56 Por. H. Chałupczak, T. Browarek, Mniejszości narodowe..., dz. cyt., s. 10-11.

57 Por. M. Barwiński, Pojęcie narodu oraz mniejszości narodowej..., dz. cyt., s. 2. 
plemienna, dodatkowo wzmocniona wspólnotą mowy i dziedzicznych wartości kulturowych, a istotnym czynnikiem wpływającym na poczucie jedności narodowej jest ziemia wspólnego zamieszkania, zwana $\mathrm{krajem}^{58}$. Biorąc pod uwagę wyżej zaprezentowane rozumienie narodu, można stwierdzić, że intencją polskiego ustawodawcy było przyznanie statusu mniejszości narodowych tym grupom społecznym, które charakteryzują się odrębnością w zakresie języka, kultury i języka od dominującej części społeczeństwa, a jednocześnie utożsamiają się ze społecznością, która jako naród zorganizowana jest w swoim państwie. W istocie wszystkie społeczności uznane na gruncie u.m.n.e. za mniejszości narodowe posiadają swoją „większość”, tj. swój punkt odniesienia w zakresie narodowej tożsamości w państwie trzecim. W tym miejscu warto zwrócić uwagę na mniejszość żydowską, która uzyskała na gruncie u.m.n.e. status mniejszości narodowej. Zastanawia bowiem, jaka byłaby decyzja ustawodawcy w tym zakresie, gdyby państwo Izrael nie powstało. Być może społeczność żydowska uzyskałaby wówczas status społeczności etnicznej, choć przecież jej odrębność, poczucie wspólnoty, kultura czy tradycja nie uległyby zmianie. Wobec tego należałoby stwierdzić, że świadomość własnej historycznej tożsamości narodowej lub etnicznej jawi się jako czynnik zewnętrzny, ustalony niejako w wyniku politycznych ustaleń.

Z kolei przesłanką uznania danej społeczności za grupę etniczną jest w myśl postanowień u.m.n.e. brak utożsamiania się z narodem zorganizowanym we własnym państwie. Według ustawodawcy mniejszość etniczna to taka zbiorowość, która, podobnie jak mniejszość narodowa, charakteryzuje się odrębnością od reszty społeczeństwa w zakresie języka, kultury czy tradycji, jednak nie utożsamia się z narodem zorganizowanym we własnym państwie. Etniczność nie

58 Por. R. Andrzejczuk, Prawa człowieka..., dz. cyt., s. 82. 
łączy się zatem z zorganizowaniem własnej państwowości. Można zatem stwierdzić, że polski ustawodawca przyjął węższe rozumienie mniejszości etnicznej, prezentowane już na gruncie niniejszej publikacji. Powstaje w takim razie pytanie, czy dla członków mniejszości etnicznej swoistym „punktem odniesienia” powinna być tożsama etnicznie grupa niezorganizowana we własnym państwie, ale jednak posiadająca swoich przedstawicieli poza granicami Polski, czy wystarczające byłoby istnienie grupy etnicznie odmiennej, ale o charakterze jedynie wewnątrzpaństwowym? Ustawodawca nie odpowiada na to pytanie. Należałoby wskazać natomiast na postanowienie Sądu Apelacyjnego w Katowicach z dnia 24 września 1997 roku, w myśl którego „przynależność danej grupy osób do mniejszości regionalnej o bardzo dużym poczuciu tożsamości ( $w$ tym również kulturowej) nie wystarcza do stwierdzenia, że dana grupa stanowi mniejszość etniczną bądź narodową. Niezbędne jest bowiem postrzeganie takiej grupy jako odrębnego narodu w powszechnej świadomości oraz przede wszystkim posiadanie większości poza granicami kraju, inaczej mówiąc mniejszość to taka grupa etniczna, która ma większość poza granicami kraju" 59 . Wobec tego nasuwa się wniosek, że warunkiem uzyskania statusu mniejszości narodowej lub etnicznej jest zawsze fakt istnienia odpowiedniej większości danej społeczności, czy to zorganizowanej we własnym państwie, czy też rozproszonej po innych państwach. Biorąc pod uwagę sytuację mniejszości etnicznych określonych na gruncie u.m.n.e., należy stwierdzić, że wszystkie z nich stanowią część większej społeczności rozproszonej w różnych państwach o niezorganizowanej własnej państwowości, tj. pozostają w warunkach tzw. diaspory.

59 Sygn. akt I ACa493/97, http://www.katowice.sa.gov.pl/container/biuletyny// do2002//biuletyn_1998_1.pdf (6.11.2018). 
Statusu mniejszości etnicznej nie przyznano natomiast społeczności śląskiej, która jeszcze na etapie prac nad u.m.n.e. zabiegała o objęcie jej stosowną ochroną na gruncie normatywnym. W czasie spisu powszechnego z 2002 roku ok. 173 tys. osób zadeklarowało narodowość śląską. Natomiast w czasie spisu powszechnego w 2012 aż 847 tys. osób zadeklarowało przynależność do narodowości śląskiej, przy czym mniej niż połowa $z$ tej liczby ( 376 tys.) wyraziła jako identyfikację pojedynczą (tj. wyłącznie śląską), częściej z kolei wskazywano identyfikację śląską łącznie z polską - 431 tys. ${ }^{60}$. Nie ulega zatem wątpliwości, że na przestrzeni niespełna dziesięciu lat znacznie wzrosła świadomość własnej tożsamości wśród Ślązaków. Czy jest to natomiast świadomość narodowa lub etniczna i czy w świetle aktualnych rozwiązań przyjętych na gruncie u.m.n.e. możliwe byłoby uznanie społeczności śląskiej za mniejszość narodową lub etniczną?

Biorąc pod uwagę elementy definicji mniejszości narodowej, a w szczególności wymóg utożsamiania się z narodem zorganizowanym we własnym państwie, nie ma wątpliwości, że mniejszością narodową Ślązacy być nie mogą. Potwierdzenie takiego stanu rzeczy znalazło się w orzecznictwie sądów polskich, kiedy działacze Śląskiego Związku Akademickiego i Ruchu Autonomii Śląska złożyli wniosek o rejestrację Związku Ludności Narodowości Śląskiej. Sąd drugiej instancji odmówił rejestracji związku, uzasadniając swój wyrok tym, iż wolność wyboru narodowości może być realizowana tylko w odniesieniu do narodów obiektywnie istniejących, ukształtowanych w procesie historycznym, a narodu śląskiego nie ma. Nie istnieje on ani w powszechnej świadomości, ani w aktach prawnych, a postrzeganie odrębności Ślązaków wiąże się tylko z historycznymi

60 Por. S. Łodziński, K. Warmińska, G. Gudaszewski, Mniejszości narodowe..., dz. cyt., s. 65. 
regionami kraju ${ }^{61}$. Pogląd Sądu Apelacyjnego w Katowicach zaaprobował również Sąd Najwyższy, który w swoim postanowieniu z dnia 18 marca 1998 roku oddalił skargę kasacyjną Komitetu Założycielskiego Związku Ludności Narodowości Śląskiej, podnosząc w nim, że w powszechnej świadomości społecznej było i jest przekonanie o istnieniu grupy etnicznej Ślązaków, która jednakże nigdy nie była uważana za odrębną grupę narodową i nie pretendowała do tego ${ }^{62}$. Takie stanowisko zajął również Europejski Trybunał Praw Człowieka w sprawie Gorzelik i inni przeciwko Polsce, oddalając skargę stowarzyszenia wyrokiem z dnia 20 grudnia 2001 roku, a następnie w składzie Wielkiej Izby wyrokiem z dnia 17 lutego 2004 roku $^{63}$. W późniejszym okresie (w roku 2005) przedstawiciele społeczności śląskiej podejmowali kolejne próby rejestracji stowarzyszenia, jednak bezskutecznie.

Brakuje zatem usankcjonowania przez państwo istnienia narodu śląskiego, czego konsekwencją było nieuznanie tej grupy regionalnej za mniejszość narodową. Z danych spisu powszechnego z 2011 roku jednoznacznie wynika jednak, że wśród Ślązaków istnieje silne poczucie narodowej tożsamości. Narodowość śląska była najliczniej deklarowaną spośród wszystkich narodowości innych niż polska. Należy zwrócić uwagę na sposób określenia definicji narodowości na gruncie art. 2 pkt 6 ustawy z dnia 4 marca 2010 roku o narodowym spisie powszechnym ludności i mieszkań w 2011 roku $^{64}$. Zgodnie z jego brzmie-

61 Wyrok Sądu Apelacyjnego w Katowicach z dnia 24 września 1997 roku, sygn. akt I ACa 493/97.

62 Postanowienie Sądu Najwyższego z dnia 18 marca 1998 roku, I PKN 4/98 (OSNApius 1995/5/170).

63 Europejski Trybunał Praw Człowieka, Wyrok z dnia 17 lutego 2004 r. Sprawa Gorzelik i inni przeciwko Polsce (Skarga nr 44158/98), https://etpcz.ms.gov.pl/ etpccontent/\$N/990000000000001_I_ETPC_044158_2098_Wy_2001-12-20_001 (10.11.2018).

64 Dz. U. z 2010 r. Nr 47, poz. 277. 
niem ilekroć w ustawie jest mowa o narodowości - przynależności narodowej lub etnicznej - rozumie się przez to deklaratywną, opartą na subiektywnym odczuciu, indywidualną cechę każdego człowieka, wyrażającą jego związek emocjonalny, kulturowy lub związany z pochodzeniem rodziców, określonym narodem lub wspólnotą etniczną. Niniejsza definicja została opracowana w oparciu o elementy wyłącznie subiektywne. Poza tym warto zauważyć, że definicja ta odnosi się do pojęcia narodowości, nie zaś narodu, który z kolei pojawia się w ustawowej definicji mniejszości narodowej. O narodowości, w myśl postanowień ustawy $\mathrm{z}$ dnia 4 marca 2010 roku o narodowym spisie powszechnym ludności i mieszkań w 2011 roku, świadczy nie tylko związek jednostki z obiektywnie istniejącym narodem, ale również ze wspólnotą etniczną. Wydaje się zatem, mając na uwadze zarówno przepisy tejże ustawy, jak i u.m.n.e., że sama deklaracja narodowości, która jest pojęciem dość pojemnym, nie może w każdym wypadku stanowić samoistnej podstawy uznania danej społeczności za mniejszość narodową. Nie może stanowić z pewnością podstawy uznania społeczności śląskiej za mniejszość narodową.

Pojawia się natomiast pytanie, czy społeczność śląska - określona $\mathrm{w}$ zaprezentowanym powyżej orzecznictwie jako grupa etniczna - w świetle ustaleń spisu powszechnego z 2011 roku i w świetle przepisów u.m.n.e. mogłaby zostać uznana za mniejszość etniczną? Wydaje się, że takie rozwiązanie nie jest wykluczone, biorąc pod uwagę elementy definicji mniejszości etnicznej określone w art. 2 ust. 3 u.m.n.e. W szczególności trzeba zauważyć, że spełniony zostałby wymóg nieutożsamiania się Ślązaków z narodem zorganizowanym we własnym państwie, gdyż nie istnieje autonomiczne państwo śląskie, przy jednoczesnym realizowaniu wymogów poczucia odrębności czy dążenia do zachowania własnej kultury tradycji czy języka. Społeczność śląska zamieszkuje obecnie przede wszystkim obszar Górnego Śląska, a także mniej licznie Śląsk Opolski, Śląsk Cieszyński 
oraz skrawek Republiki Czeskiej ${ }^{65}$. Nie jest to jednak rozproszenie o takim charakterze, jak w przypadku mniejszości etnicznych uznanych na gruncie u.m.n.e., które posiadają etymologię pochodzenia wyraźnie odrębną od polskiej, ale formalnie taki warunek uznania za mniejszość etniczną (tj. pozostawanie w diasporze z resztą grupy etnicznej) nie został w u.m.n.e. określony. Być może w takim razie należałoby uznać Ślązaków za grupę regionalną, tj. etnograficzną, nie zaś za grupę/mniejszość etniczną.

Grupa etnograficzna rozumiana jest jako grupa wyróżniona w badaniach etnograficznych na podstawie odrębnych, obiektywnych cech kulturowych oraz, niekiedy, świadomości odrębności i poczucia wspólnoty grupowej. Stanowi część grup etnicznych lub występuje na ich pograniczu. Grupy etnograficzne wydzielano najczęściej, biorąc pod uwagę różnice w kulturze ludowej ${ }^{66}$. Pojawiają się również teorie, w myśl których grupa etnograficzna to grupa uważana za część mozaiki kulturowej danego społeczeństwa narodowego. Podkreśla się również, że niewykluczone jest zjawisko przekształcenia się grupy etnograficznej w grupę etniczną, zwłaszcza w przypadku, gdy grupa etnograficzna funkcjonuje na pograniczu grup etnicznych ${ }^{67}$. Jak wynika z zaprezentowanych definicji, trudno jednoznacznie określić status społeczności śląskiej i przypisać tej zbiorowości ściśle określoną kategorię etnograficzną, tym bardziej że brakuje jednolitych definicji w tym zakresie (zarówno w prawie, socjologii, etnografii

65 Por. Biuletyn Sejmowej Komisji Mniejszości Narodowych i Etnicznych z 2008 roku, $\mathrm{nr} 30$ (1588/vi) http://orka.sejm.gov.pl/Biuletyn.nsf/o/Ao7628CB E422AD6CC125752300503C3F/\$file/0158806.pdf (10.11.2018).

66 Por. Encyklopedia PWN, https://encyklopedia.pwn.pl/haslo/grupa-etnograficzna;3908272.html (10.11.2018).

67 Por. K. Radłowska, Między grupa etnograficzną a narodem. Status Tatarów polskich $w$ świetle dotychczasowych badań, „Pogranicze. Studia społeczne” 23 (2014), s. 156-157. 
czy politologii) i jasno określonych kryteriów kwalifikacji. Nie ulega wątpliwości, że Ślązakom bliżej jest, biorąc pod uwagę wymogi zawarte w u.m.n.e., do mniejszości etnicznej niż narodowej, choć i w tym wypadku nie brakuje pewnych wątpliwości.

Również społeczność kaszubska silnie akcentuje swoją regionalną tożsamość, co znalazło potwierdzenie w czasie spisu powszechnego w 2011 roku, kiedy to 232,5 tys. osób zadeklarowało narodowość kaszubską ${ }^{68}$. Odrębność Kaszubów przejawia się przede wszystkim w języku, który w odróżnieniu od mowy śląskiej uznany został na gruncie u.m.n.e. za język regionalny. Przypuszczać można, że takie rozwiązanie spełniło oczekiwania znacznej części społeczności kaszubskiej w zakresie ochrony ich odrębności, aczkolwiek wydaje się, że charakter tej odrębności jest zbliżony do odrębności społeczności śląskiej, a zatem rozważania w zakresie możliwości pretendowania Ślązaków do statusu mniejszości etnicznej pozostają aktualne także w odniesieniu do społeczności kaszubskiej.

Można zatem stwierdzić, że definicje mniejszości narodowych i etnicznych określone w u.m.n.e. nie są jednoznaczne, co wynika na pewno z niejednoznaczności pojęć „narodowy” i „etniczny”, nie tylko na gruncie prawa, ale także innych nauk społecznych. Wobec tego należy mieć świadomość, że katalog mniejszości narodowych i etnicznych ujętych w u.m.n.e. niekoniecznie ma charakter niezmienny, gdyż wciąż istnieją społeczności, które pretendują do uznania ich za mniejszość narodową bądź etniczną i które na skutek postępujących przemian kulturowych i społecznych czy przemian w zakresie postrzegania własnej tożsamości być może kiedyś taki status uzyskają.

68 Por. Struktura narodowo-etniczna..., dz. cyt., s. 31. 


\section{Podsumowanie}

Podsumowując prowadzone rozważania, należy stwierdzić, że zdefiniowanie pojęcia mniejszości narodowych i mniejszości etnicznych jest trudne z tego względu, że w zasadzie brakuje jednoznacznych definicji terminów „etniczny” i „narodowy” na gruncie językowym i często są one stosowanie zamiennie. W niniejszej publikacji zaprezentowano pojawiające się w literaturze tematu sposoby określania mniejszości narodowych i etnicznych, jednak ich mnogość i nierzadko rozbieżność uniemożliwia określenie w sposób pewny i kategoryczny znaczenia tych pojęć. Analiza ich warstwy językowej oraz kontekstu pozwala z pewną dozą ostrożności stwierdzić, że mniejszość narodowa ma charakter niejako wtórny, bardziej zaawansowany czy też kwalifikowany w stosunku do mniejszości etnicznej. Pojęcie grupy etnicznej i mniejszości etnicznej wydaje się być pojęciem szerszym, bardziej pojemnym niż pojęcie narodu i mniejszości narodowej. Mniejszość etniczna jawi się w świetle prezentowanych definicji jako społeczność, która w stosunku do reszty ludności danego terytorium charakteryzuje się własną, odrębną genezą pochodzenia, specyficzną kulturą, tradycją, językiem i dąży do zachowania tej odrębności, jednak nie funkcjonuje w ramach własnej zorganizowanej państwowości i też z tak zorganizowaną społecznością się nie utożsamia. Wydaje się, że mniejszość etniczna to z kolei część pewnej grupy etnicznej, która znalazła się w sytuacji, kiedy nie dominuje na danym terytorium (zwykle chodzi o terytorium państwa) i funkcjonuje obok większościowej pod względem liczebności, odmiennej etnicznie grupy. Z kolei mniejszość narodowa stanowi część narodu - tj. grupy etnicznej, którą łączy wspólnota dziejowa i która funkcjonuje w ramach zorganizowanej, własnej państwowości, na określonym terytorium - oraz stanowi społeczność mniejszościową, zwykle na obszarze innego państwa. Wobec tego można stwierdzić, że etniczność to jeden z elementów tożsamości narodowej. 
Wyżej zaprezentowane rozumienie mniejszości narodowych i etnicznych nie jest jednak doskonałe, gdyż nie sposób zaprzeczyć istnieniu narodu żydowskiego zanim powstało państwo Izrael, a społeczność ta była rozproszona w diasporze. Podobnie jak nie odmawia się prawa do poczucia polskiej narodowości Polakom w okresie rozbiorów, gdy nie istniało państwo polskie ${ }^{69}$. Być może niecelowe jest dokonywanie rozróżnienia tych dwóch rodzajów społeczności na gruncie normatywnym i właściwe byłoby posługiwanie się jednolitym, stosunkowo szerokim określeniem „niedominującej grupy etnicznej”. Jak zauważono w trakcie prowadzonych rozważań, na gruncie aktów prawa międzynarodowego pojęcia mniejszości narodowych $i$ etnicznych są stosowane niejako obok siebie, jednak nie są w żaden sposób zdefiniowane. Próby określenia definicji w zakresie międzynarodowego systemu ochrony praw człowieka o charakterze uniwersalnym pojawiały się wyłącznie na gruncie dokumentów prawnie niewiążących i w zasadzie ograniczały się jedynie do propozycji w zakresie rozumienia pojęcia mniejszości narodowych. Jeśli chodzi z kolei o regionalne systemy ochrony praw człowieka, to także pojęcie mniejszości narodowych stosowane jest na gruncie aktów prawa międzynarodowego częściej (Rada Europy, KBWE/oBWE, wNP, Inicjatywa Środkowoeuropejska). Z kolei odniesienie do społeczności mniejszościowych w źródłach prawa Unii Europejskiej ma zwykle swoje miejsce w tzw. klauzulach antydyskryminacyjnych, w których często pojawia się określenie „pochodzenie etniczne”.

Jeśli chodzi o polskie rozwiązania w zakresie definiowania społeczności mniejszościowych, to określono na gruncie ustawowym

69 Por. K. Zieliński, M. Segal, M. Zani, R. Silberstein, S. Glitzenstein, K. E. Lyamzina, Sytuacja mniejszości narodowych, etnicznych i religijnych w wybranych państwach Unii Europejskiej ze szczególnym uwzględnieniem mniejszości żydowskiej, Warszawa 2017, s. 14. 
zarówno definicję mniejszości narodowych, jak i mniejszości etnicznych, co jest raczej rzadkością w ustawodawstwach innych państw europejskich. Prawdopodobnie rozwiązanie to podyktowane zostało wyraźnym rozróżnieniem na gruncie Konstytucji RP z 1997 roku obu społeczności mniejszościowych (art. 35). W u.m.n.e. nie tylko określono przesłanki uznania danej zbiorowości za mniejszość narodową i etniczną (zarówno o charakterze obiektywnym, jak i subiektywnym), ale również enumeratywnie wymieniono społeczności, które taki status uzyskały. To rozwiązanie, w odróżnieniu od określenia wyłącznie przesłanek uznania za mniejszość, bez wyraźnego wyszczególnienia konkretnych społeczności, z pewnością w sposób jednoznaczny kształtuje sytuację prawną zainteresowanych społeczności.

Przesłanki uznania za mniejszość narodową i etniczną w zasadzie są tożsame $\mathrm{z}$ przesłankami proponowanymi w ramach rozwiązań międzynarodowych (m.in. kryterium obywatelstwa). Należy zauważyć, że najistotniejszą cechą, która rozróżnia w u.m.n.e. mniejszość narodową od etnicznej jest przesłanka utożsamiania się z narodem zorganizowanym we własnym państwie (mniejszość narodowa) oraz brak takiego utożsamiania się (mniejszość etniczna). Ustawodawca polski zdecydował się zatem na zastosowanie tzw. kryterium instytucjonalnego, które $\mathrm{z}$ kolei nie pojawia się w aktach prawnych o charakterze międzynarodowym. Mniejszość etniczną można zatem postrzegać jako część grupy etnicznej, która nie wykształciła się jako naród zorganizowany w ramach własnej państwowości i która tradycyjnie zamieszkuje na terytorium Polski. Jak wspomniano jednak powyżej, problemów interpretacyjnych dostarcza samo rozumienie pojęcia grupy etnicznej i jej ewentualne odróżnienie od grupy etnograficznej. W tej sytuacji pojawiają się dążenia innych społeczności (w szczególności Ślązaków) - nieuznanych jak dotąd na gruncie u.m.n.e. za mniejszości - do uzyskania takiego statusu. Kwestia przyznania społeczności śląskiej statusu mniejszości pozostaje wciąż aktualna 
w dyskursie publicznym, a wątpliwości ustawodawcy w zakresie uznania tej zbiorowości za mniejszość na gruncie normatywnym wydają się mieć zarówno charakter prawny, jak i pozaprawny. Być może wątpliwości natury politycznej są nawet w tym wypadku dominujące.

Trzeba mieć na względzie to, że ciągle postępujące przemiany kulturowe i społeczne czy przemiany w zakresie postrzegania własnej tożsamości oraz ewoluowanie grup etnograficznych w grupy etniczne mogą spowodować w przyszłości zmiany w katalogu mniejszości narodowych i etnicznych na gruncie u.m.n.e.

\section{Streszczenie}

Gwarancje w zakresie ochrony praw mniejszości narodowych i etnicznych stały się przedmiotem zainteresowania społeczności międzynarodowej po zakończeniu II wojny światowej. Uznano wówczas, że zapewnienie tym grupom społecznym możliwości pielęgnowania swojej tożsamości, odrębnej od tożsamości reszty społeczeństwa, powinno stanowić jeden z filarów dojrzałej demokracji. To także swego rodzaju filar bezpieczeństwa, gdyż niejednokrotnie nieporozumienia na tle narodowościowym były źródłem konfliktów o charakterze międzynarodowym. Z tego względu odpowiednie gwarancje dla mniejszości narodowych i etnicznych zostały włączone do międzynarodowego systemu ochrony praw człowieka. Podstawową kwestią pozostaje niewątpliwe sposób definiowania mniejszości narodowych i etnicznych, który na gruncie prawa międzynarodowego nie został ujednolicony. Przyznanie społecznościom mniejszościowym na gruncie prawa międzynarodowego pewnych gwarancji nie zawsze wiąże się nawet z określeniem w aktach prawa międzynarodowego ich definicji; kwestię takiego ustalenia pozostawia się w gestii poszczególnych państw. W publikacji podjęto próbę przedstawienia sposobu definiowania mniejszości narodowych i etnicznych w piśmiennictwie oraz różnic, jakie zaznacza się w rozumieniu pojęcia „naród” i „grupa etniczna”. Scharakteryzowano sposób definiowania tych grup społecznych w aktach prawnych uchwalanych w ramach uniwersalnego systemu ochrony praw człowieka oraz w ramach regionalnych systemów ochrony praw mniejszości, funkcjonujących w ramach Rady Europy, oвwE, WNP, Inicjatywy Środkowoeuropejskiej oraz Unii Europejskiej. W końcu 
podjęto próbę charakterystyki i oceny polskich rozwiązań w zakresie ochrony i sposobu definiowania mniejszości narodowych i etnicznych na gruncie normatywnym, uwzględniając również problematykę społeczności śląskiej pretendującej do uznania jej za mniejszość narodową. Dokonano także porównania konstrukcji definicji przyjętych przez polskiego ustawodawcę ze standardami międzynarodowymi w tym zakresie.

Słowa kluczowe: mniejszości narodowe i etniczne, naród, grupa etniczna, ochrona praw człowieka, ustawa o mniejszościach narodowych i etnicznych oraz o języku regionalnym

\section{Summary}

Definition of national and ethnic minorities in Polish legislation against the background of international solutions

Guarantees regarding the protection of the rights of national and ethnic minorities became the subject of interest of the international community after the end of World War II. It was then decided that providing these social groups with the opportunity to cultivate their identity, separate from that of the rest of society, should constitute one of the pillars of a mature democracy. It is also a kind of security pillar, as nationality misunderstandings have often been the source of international conflicts. For this reason, appropriate guarantees for national and ethnic minorities have been incorporated into the international system of human rights protection. The basic issue is undoubtedly the way of defining national and ethnic minorities, which has not been unified on the basis of international law. Granting certain guarantees to minority communities under international law does not always involve specifying their definitions in acts of international law, leaving the question of such determination to individual states. The publication attempts to present the way of defining national and ethnic minorities in the literature and the differences that are marked in the understanding of the concept of "nation" and "ethnic group." Characterized is the way of defining these social groups in legal acts adopted within the universal system of human rights protection and within the regional systems of protection of minority rights, operating within the Council of Europe, osce, the Commonwealth of Independent States, the Central European Initiative and the European Union. Finally, an attempt was made to characterize and evaluate Polish solutions in the 
field of protection and the way of defining national and ethnic minorities on a normative basis, also taking into account the problems of the Silesian community that aspires to be recognized as a national minority. The construction of definitions adopted by the Polish legislator was also compared with international standards in this regard.

Keywords: national and ethnic minorities, nation, ethnic group, protection of human rights, the act on national and ethnic minorities and on the regional language 